\title{
Duethe Heir's Oral Will of the Heirth before the Tradition of Batak Toba Instruction Happened on the Instructed Land
}

\author{
Imman Yusuf Sitinjak ${ }^{1}$, Humala Sitinjak ${ }^{2}$, Sariaman Gultom ${ }^{3}$ \\ 1,2,3 Universitas Simalungun, Indonesia \\ immanjoes@gmail.com,sitinjakhumala@gmail.com,sariamangultom1966@gmail.com
}

\begin{abstract}
This research aims to identify and discuss the problems and symptoms that occur when death and open inheritance occurs, while the will of the heir has been said verbally to the heirs in the traditional inheritance of Batak Toba. This research discusses the problems that arise when the traditional inheritance of Batak Toba is carried out and there is a verbal will by the heir, especially in the heir's land ownership. The problem that arises when open inheritance is carried out in customary inheritance is a dispute from the heirs who are dissatisfied with the unequal distribution to the heirs, while the heirs who get a portie in inheritance are boys, while for women it is a form of gift given male heirs to girls. In the event of a dispute over inherited land, when the name of the land is transferred to the BPN office, there will be obstacles.
\end{abstract}

Keywords

Heir; the heir's oral will; traditional inheritance

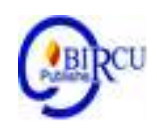

\section{Introduction}

Land is immovable property which is very important and has a very high value today. In Law Number 5 of 1960 concerning Basic Agrarian Regulations, what is meant by land is the surface of the earth. In Article 4 paragraph (1) it is stated that "On the basis of the right to control of the state as meant in Article 2, it is determined that there are various rights to the surface of the earth, which are called land, which can be given to and owned by people either individually or collectively same with other people as well as legal entities ". (UUPA, Article 4).

In the opinion of Ni Luh Ariningsih Sari (2021, 991-998) that land is a natural wealth controlled by the state and used for the maximum welfare of the people, this is stated in Article 33 paragraph (3) of the 1945 Constitution, which is reaffirmed in Article 2 paragraph (1) of Law Number 5 Years 1960 concerning the Basic Fundamentals of Agrarian Affairs stated; On the basis of the provisions in Article 33 paragraph 3 of the Basic Law and matters as referred to in Article 1, the earth, water and space, including the natural resources contained therein, are at the highest level controlled by the state, as an organization of power.

The increasingly difficult lives of these people due to the covid 19 virus have worsened the financial condition of the Indonesian people so that economic problems have become the biggest problem after health for the community. The need for land to build shelter and can also be used for plantation land becomes difficult for the community because land prices vary and are expensive due to its sometimes strategic location, as well as difficulties in buying land because management or implementation of the name reverses becomes difficult because ownership of the land is land legacy.

Even though it needs to be understood that the importance of title to land if you want to own land. AP Parlindungan (1984: 65) stated thatProperty rights according to UUPA No.5 of 1960. Article 20 paragraph 1 of UUPA states the definition of property rights as follows: 
"Property rights are hereditary, strongest and fulfilled rights that can be owned by people over land, taking into account the provisions in Article 6". From this opinion, it can be understood that with the existence of a land certificate as a property right, the land owner has the strongest and fullest hereditary rights to the land.

However, the problem that arises is when the land is inherited land, where the evidence that must be fulfilled to be able to declare the land belongs to him is a confession, as well as other written evidence. Inheritance is not a new problem anymore, because it involves assets which the heirs desire to own and become one of the debates in the distribution. Especially in the traditional inheritance of Batak Toba, if you have an only child, it is possible that the distribution of inheritance is quite easy because it will be passed down to only children. However, having more than one child is a difficult problem when there is a distribution of inheritance. Because the inherited land according to the traditional Batak Toba inheritance fell to the youngest son.

The customary inheritance law in Indonesia is strongly influenced by the principle of lineage that applies to the community concerned, which may be a pure patrilineal, patrilineal alternating (matrilineal or bilateral alternerend) (although it is difficult to confirm where it applies in Indonesia), there are also multiple unilateral principles or (dubbel-unilateral). The principles of lineage mainly affect the determination of heirs and the portion of inherited inheritance (both material and immaterial). (Zuhirsyan et al, 2019)

Based on the above background, the researcher feels very interested in further research. The formulation of the problem in this study can be formulated in the form of a main question, namely what problems arise when the traditional inheritance of Batak Toba is carried out and there is an oral will by the heir, especially in the heir's land ownership?

\section{Research Methods}

Research according to Sukandarrumidi (2006: 111) is a research activity carried out using systematic, scientific methodology in which the aim is to obtain something new or original when making efforts to solve a problem that can arise in society at any time.

In this study, the method used to discuss this problem is to use qualitative research methods with the Normative Juridical approach, which is based on the main legal materials by examining theories, concepts, and principles of law and legislation relating to this research. In this research, it is used by reading books and legal experts and regulations / laws to discuss writing problems in accordance with the theory and legal basis.

Solving a legal issue through legal research requires certain approaches as a basis for formulating appropriate arguments. There are various approaches in legal research, namely the statute approach, the case approach, the historical approach, the comparative approach, and the conceptual approach.

In carrying out research on "The Effects of the Oral Will of Sipewaris Before the Toba Batak Traditional Inheritance Against Inherited Land", it is necessary to use a conceptual approach, which is a type of approach in legal research that provides an analysis point of view of problem solving in legal research from the perspective of The concept of customary inheritance law which is the background, or even can be seen from the values contained in the norming of a regulation in relation to the concepts of sharing the traditional inheritance of Batak Toba used. 


\section{Discussion}

Inheritance assets are all assets of a deceased person, in the form of all assets of the deceased after deducting all debts. If the element of inheritance or inheritance is not present, it means that the person who died did not leave any inheritance or inheritance, inheritance is irrelevant. However, if the element of a person or family member is not present, inheritance is still relevant because the inheritance of the deceased person falls on the state (Oemarsalim, 1987: 24)

It is very important to know that the law of inheritance is a law that regulates the transfer of assets left by someone who dies and its consequences for the heirs. (Effendi Warinangin, 1997: 3) The Civil Code itself does not provide an understanding of inheritance law, only in Article 830 states that "inheritance only takes place because of death" (KUHPerdata, 2007: 194)

According to the Civil Code, the principle of inheritance is open inheritance (can be inherited to another party) in the event of a death (Article 830 of the Civil Code) / death of the heir, as well as the existence of a blood relationship between the heir and the heir, is excluded for the husband or wife of the heir (Article 832 of the Civil Code). The provisions for them are still bound in marriage when the heir dies, which if they are divorced when the heir dies, then the husband or wife is not the heir of the heir according to civil law.

According to Anasitus Amanat (2001: 6) that heirs (erfgenaam) are all people who are entitled to inheritance. In the Civil Code, the heirs are members of a legal blood family or outside of marriage as well as husbands and wives who live outside of marriage and husbands and wives who have lived the longest (Article 832 of the Civil Code), as well as Article 833 of the Civil Code, it is said that all heirs automatically because of the law obtain ownership rights to all goods, all rights and all receivables that pass away.

In inheritance law applies a principle, which is only rights and obligations in the legal field of property that can be inherited, in other words only rights and obligations that can be valued in money. Sealin also applies a principle, that if a person dies, immediately all his rights and obligations are transferred to all his heirs.

Another thing for the Toba Batak indigenous people, inheritance is something that must be done according to the customs in general and the heirs in the implementation of the inheritance of the Toba Batak custom are boys.

According to Abdulkadir Muhammad (2010: 197) that the Civil Code does not differentiate between boys and girls, between husband and wife. They are entitled to inherit by getting an equal share. The male share is the same as the girl's share. The share of a wife or husband is the same as the share of children if children are born from that marriage. When connected with the hereditary system, the Criminal Code adheres to a bilateral hereditary system. Each person connects himself to the offspring of his father or mother. that is, the heir has the right to inherit from the father if the father dies and the right to inherit from the mother if the mother dies. This is because according to Surini Ahlan Sjarif and nurul Elmiyah (2005: 11) that the heir is a family member of a deceased person who replaces the heir's position in the field of wealth law due to the death of the heir.

Article 832 of the Civil Code stipulates that those who are entitled to be heirs are blood relatives and living husband / wife. If none of these are entitled to become heirs, the state is as explained by Anasitus Mandate (2001: 6) above.

Blood families and husband / wife are classified into the following four groups:

a. Children or offspring and husband / wife who are still alive.

b. Parents (mother's father) and siblings heir.

c. Grandparents or other ancestors in a straight line up (article 853 of the Civil Code). 
d. Relatives in sideways line up to the sixth level. (Article 861 of the Civil Code).

It is important to understand that the heirs who inherit directly are the heirs who receive an inheritance based on their own position towards the heir, for example, as the son of the heir, the wife / husband of the heir. Meanwhile, a substitute heir is an heir who replaces the person entitled to inherit the estate of the heir because the person concerned died earlier than the heir. For example, the father died earlier than the grandfather, therefore the children of the father who died appeared to replace their father's position as the grandfather's heir. This substitution occurs in a downward line and can occur indefinitely. Each heir who dies before the heir can be replaced by his children. If more than one child is substituted, the replacement is counted as one branch which means, that all substitute children can have the same share of the part that is substituted. The replacement of heirs can also occur falling to the family in a sideways line where each heir, both siblings and half siblings, if they die first, are replaced by their children. This replacement can also occur indefinitely.

For the Batak Toba indigenous people, boys have a high position in the family where boys play the role of inheriting the lineage in the Batak Toba family. So that the inheritance of the parents will also fall to the son when death occurs.

In the Toba Batak indigenous community, the biggest son is indeed the heir of the family lineage, but the most frequent or main property of land goes to the youngest son. Not only that, sometimes parents have mandated (the will before death) about the part of their children as heirs orally. It is this oral existence that is difficult to prove by the community when there is a traditional inheritance from Batak Toba.

It should be understood that the legal consequence of a marriage is the implementation of inheritance at a later date. If a member of the community dies, one of the consequences in law is regarding the status of the property he left behind. When the status of this property is linked to other people who are still alive, what is known as inheritance will arise.

The provisions of inheritance law in the Civil Code (BW) do not define inheritance, but only determine the time at which the inheritance occurs (article 830 of the Civil Code). Article 830 of the Civil Code also states that inheritance only occurs because of death. So it is concluded that the death of a person (heir) is the main condition for inheritance. With the death of a person, all of his assets will be transferred to the heirs. (Imman Yusuf Sitinjak, 2014: 53)

According to the law, the main requirement to become an heir is blood relationship, thus meaning that aspects of family law also determine the inheritance law. Meanwhile, many legal experts argue that placing the Law of Inheritance as a separate part is not covered by the Law of Assets or Family Law. (Imman Yusuf Sitinjak, 2014: 54)

According to Hertiana Eva YL Tobing, (2018: 5) The inheritance distribution system in the Toba Batak Customs itself is a lot of discrimination that is obtained by Batak Toba women, where in today's development Batak women are suing for the right to inherit to the court accompanied by a verdict. - a judge's decision in court which gave equality and position for women in the distribution of inheritance in the Toba Batak community. The decision by equalizing the rights of men and women also affected the inheritance change process among the Toba Batak indigenous people.

Meanwhile, the issue of inheritance that needs to be discussed at this time is the existence of the will of the heir before death occurs. The will was pronounced in front of all his children so that it was carried out after his death. However, many of them as the heirs instead want to control the parts that do not belong to them according to the will of the heir. The background reason is dissatisfaction with the distribution of inheritance and also cannot be authentically proven that there is a will from the heir to the existing inheritance. 
Many problems arise if the heirs do not want to recognize the rights of other heirs, namely where the heirs cannot reverse the name of their rights to the inherited land. In terms of acknowledging, recognition of the rights of others is very important, where recognition means recognizing the existence of the rights of others. For example, in terms of obtaining land title certificates, the importance of recognition from neighboring lands that the land is theirs. Likewise, if the land is inherited land, the other heirs must also make a recognition or acknowledge that the land is their right as part of the heir.

It is very understandable that the current land price is soaring in price. So that many want to buy for investment or sell because of the price to improve their economy. However, because the land is inherited land, it is very difficult for the heirs to own it. In order to be able to solve the problem of the inherited land which is his right by the will of the heir, it is important for the heir to write down his will in a will other than by verbal speech. And in this letter, it is important to write that all heirs who have signed in this letter "have agreed and recognized their respective rights in the will, which later on this letter can be used as a letter of recognition of the rights of the heirs and power of attorney for each expert. inheritors to be able to administer part of their rights to the inheritance. "

According to Salim HS, an heir according to a will is an heir who receives an inheritance due to a will (testamen) from the heir to the heir as outlined in a will (2002: 142) because the Civil Code itself states (Article 875 of the Civil Code) that a will (testamen)) is a deed which contains a statement by a person about what he wants to happen after he dies and is revoked by him. If it is reviewed and linked to the traditional inheritance of the Batak Toba with the contents of the Civil Law, it should be stated that the will is written in writing. This is done so that the will of the heir in the Toba Batak can be proven in writing in accordance with the provisions of the Civil Code as a will. In the case of the will, the heir as the owner of the property has the absolute right to regulate and wants to do whatever he wants with his property.

According to M. Wijaya. S (2014)A will is made with the aim that the heirs cannot know whether the inheritance left by the heir will be inherited to his heir, or even be inherited to another party who is not his heir at all until the time of reading the will. And this often creates problems between the heirs and those who are not heirs, but according to the will of the person who is not the heir will receive a will. Of course there will be parties who feel aggrieved and submit rebuttals / cancellations regarding the truth of the contents of the will made by the heir. Therefore, wills are valid after the death of the heir, so it is very difficult to prove their validity because there are also wills made without the intervention of a notary public.

The need for written evidence is a need as authentic evidence if a problem occurs in the future. Because verbally it cannot prove someone's wishes or words in a real and firm way, because those who know are only those who are present, and even those who are present cannot necessarily explain again as said first, and if it becomes an implementation later, it is not certain that those who are present remember or want to fulfill that verbal wish if there is no interest in it. Likewise speaking of inheritance, if someone does not have an interest in that part of the property, especially as an heir, then the existence of a will or wish that is only in verbal form can be a big problem for those who are heirs, where there is always a desire to control the inheritance for them as experts.

With this letter, it is hoped that it can solve the problems of the heirs to be able to carry out the will of the heir after experiencing death and open inheritance. It is even better if the will made or the will of the heir is made at the notary's office where the will is not only held by the heirs but is also registered and kept with the ministry of law and human rights. That way, there will be no more disputes regarding the inheritance of the Batak Toba traditional inheritance if there is the will of the heir to do before he dies. 


\section{Conclussion}

As a result of the verbal will of the inheritor before the inheritance of the Toba Batak custom to the inherited land, the heirs cannot recognize the rights of other heirs based on the will of the heir if the inheritance has been opened. This happens because the heirs and states that there is no authentic evidence that proves that the property belongs to the heirs who were appointed based on the will of the heir orally. Therefore the importance of the will of the heir not only verbally but also must be stated in writing and the heir's approval and recognition of the rights of the respective heirs. And if possible, the making of a will is done at the notary office.

\section{References}

Abdulkadir Muhammad. (2010). hukum perdata Indonesia, PT. Citra Aditya Bakti, Bandung. Anasitus Amanat. (2001).Membagi warisan Berdasarkan Pasal-Pasal Hukum Perdata BW, PT Raja Grafindo Persada, Jakarta.

Hertiana Eva Y L Tobing. (2018). Penerapan Prinsip Dalam Waris Adat Batak Toba Antara Halak Batak Yang Masih Tinggal Di Wilayah Adat Dan Yang Diluar Wilayah Adat,

Skripsi Fakultas Hukum Universitas Negeri Semarang, Semarang.

Imman Yusuf Sitinjak. (2014). Analisis Hukum Terhadap Kedudukan Ahli Waris Dalam Perkawinan Adat Tionghoa Di Pematangsiantar, Tesis UMSU, Medan.

Kitab Undang-Undang Hukum Perdata, Wipress, Jakarta, 2007

Ni Luh Ariningsih Sari, Konsep Hak Menguasai Negara Terhadap Tanah Dalam Hukum Tanah (UUPA) Dan Konstitusi, Jurnal Ganec Swara Vol. 15, No.1, Maret 2021, Hal 991-998, http://journal.unmasmataram.ac.id/index.php/GARA/article/view/202

Oemarsalim. (1987). Dasar-Dasar hukum waris di Indonesia, Bina Aksara, Jakarta.

Parlindungan A.P.(1984). Komentar Atas Undang-Undang Pokok Agraria, Alumni, Bandung, Tahun.

Peranginangin. Effendi. (1997). Hukum Waris, Raja Grafindo Persada, Jakarta.

Salim HS. (2002). Pengantar Hukum Perdata Tertulis (BW), Sinar Grafika, Jakarta.

Sukandarrumidi. (2006). Metodologi Penelitian: Petunjuk Praktis untuk Peneliti Pemula, Gajah Mada University Press, Yogyakarta.

Surini Ahlan Sjarif dan nurul Elmiyah. (2005). Hukum Kewarisan Perdata Barat, Fakultas Hukum Universitas Indonesia, Jakarta.

Undang-undang Nomor 5 Tahun 1960 tentang UUPA Pasal 4

Wijaya. S. M. (2014). Tinjauan Hukum Surat Wasiat Menurut Hukum Perdata, Jurnal Ilmu Hukum Legal Opinion Edisi 5, Volume 2, Tahun.

Zuhirsyan, M. et al. (2019). Implementation of Heritage Distribution in the Community in Islamic Law Antropology Perspective (Study On Simalungun Tribe In Kuta Baru Village, Tebing Tinggi, Serdang Bedagai Regency). Budapest International Research and Critics Institute-Journal (BIRCI-Journal). P. 477-486. 